\title{
SENSORY IMPACT OF ALTERNATIVE AGEING TECHNOLOGY FOR THE PRODUCTION OF WINE BRANDIES
}

\section{IMPACTO SENSORIAL DE TECNOLOGIA DE ENVELHECIMENTO ALTERNATIVA PARA A PRODUÇÃO DE AGUARDENTES VÍNICAS}

\author{
Ilda Caldeira $^{1,2, *}$, Ofélia Anjos ${ }^{3,4}$, A. Pedro Belchior ${ }^{1}$, Sara Canas ${ }^{1,2}$ \\ ${ }^{1}$ Instituto Nacional de Investigação Agrária e Veterinária - Unidade Estratégica de Investigação e Serviços de Tecnologia e Segurança Alimentar - \\ Laboratório de Enologia - Unidade de Investigação de Viticultura e Enologia. Dois Portos, Quinta da Almoínha, 2565-191 Dois Portos. Portugal. \\ ${ }^{2}$ ICAAM - Instituto de Ciências Agrárias e Ambientais Mediterrânicas, Universidade de Évora, Pólo da Mitra, Ap. 94, 7002-554 Évora, Portugal. \\ ${ }^{3}$ Instituto Politécnico de Castelo Branco, Apartado 119, 6001-909 Castelo Branco, Portugal. \\ ${ }^{4}$ Centro de Estudos Florestais, Instituto Superior de Agronomia, Universidade de Lisboa, 1349-017 Lisboa. Portugal.
}

*corresponding author: Tel:+351261712106, fax: +351261712426, email: ilda.caldeira@iniav.pt

(Received 03.01.2017. Accepted 01.03.2017)

\section{SUMMARY}

The production of wine brandies requires their stage in wooden barrels, for a minimum period of time, a process called ageing or maturation. Due to the high cost of this process, alternative technologies are being studied in order to accelerate the ageing process, such as the use of wood fragments inside of stainless steel tanks. The present work evaluates the influence of different ageing technologies on the sensory profile of the brandy. A brandy was aged, during two years, in $650 \mathrm{~L}$ wooden barrels and in $3000 \mathrm{~L}$ stainless steel tanks. Both had Limousin oak (Quercus robur) and Portuguese chestnut staves (Castanea sativa). The brandy samples were profiled by descriptive sensory analysis during the ageing period.

The results showed that the kind of ageing system influences topaz, golden, woody, caramel, coffee, green and unctuous attributes, as well as the overall brandy quality. Despite these differences, the multidimensional analysis of the sensory results was not able to clearly distinguish the brandy samples from different ageing systems.

The results, obtained at industrial scale, revealed an interesting alternative for the manufacturers: wine brandies can be produced through the use of wooden staves inside stainless steel tanks. Since this alternative ageing system provides a similar brandy sensory profile than the one obtained through wooden barrels, this new data can be used by researchers and manufacturers in order to develop new products. Furthermore, this alternative ageing technology allows the reduction of the ageing process costs.

\section{RESUMO}

A produção de aguardentes vínicas requer o seu estágio em vasilhas de madeira, por um período mínimo de tempo, processo que se designa por envelhecimento ou maturação. Devido ao elevado custo deste processo, têm sido estudadas tecnologias alternativas para acelerar o processo de envelhecimento, como o uso de fragmentos de madeira aplicados dentro de depósitos de aço inoxidável.

O presente trabalho avalia a influência de diferentes tecnologias de envelhecimento no perfil sensorial da aguardente vínica envelhecida. Uma aguardente foi envelhecida, durante dois anos, em vasilhas de madeira de $650 \mathrm{~L}$ e em depósitos de aço inoxidável de $3000 \mathrm{~L}$. Em ambos os sistemas usou-se simultaneamente madeira de carvalho Limousin (Quercus robur) e madeira de castanheiro (Castanea sativa). As amostras de aguardentes foram recolhidas e avaliadas pelo painel de prova, por análise sensorial descritiva, durante o período de envelhecimento.

Os resultados mostraram que o sistema de envelhecimento influencia os atributos topázio, dourado, madeira, caramelo, café, herbáceo e untuoso, bem como a qualidade global da aguardente. Apesar dessas diferenças, a análise multidimensional dos resultados sensoriais não permitiu distinguir claramente as amostras de aguardentes de diferentes sistemas de envelhecimento.

Os resultados, obtidos à escala industrial, evidenciam a existência de uma alternativa interessante para os produtores: as aguardentes vínicas poderão ser produzidas através do uso de fragmentos de madeira aplicados em depósitos de aço inoxidável. Dado que este sistema de envelhecimento alternativo proporciona um perfil sensorial da aguardente semelhante ao obtido com as vasilhas de madeira, estes novos dados podem ser utilizados por investigadores e produtores para o desenvolvimento de novos produtos. Esta tecnologia alternativa de envelhecimento apresenta ainda a vantagem de permitir uma redução dos custos do processo de envelhecimento.

Key words: sensory profile, brandies, ageing, wooden barrel, wood staves.

Palavras-chave: perfil sensorial, aguardentes vínicas, envelhecimento, vasilha, aduelas de madeira.

12

This is an Open Access article distributed under the terms of the Creative Commons Attribution License

(http://creativecommons.org/licenses/by/4.0), which permits unrestricted use, distribution, and reproduction in any medium, provided the original work is properly cited. 


\section{INTRODUCTION}

The wine brandy, the distilled product from fermented grapes, must stay in wooden barrels. This process, called maturation or ageing, should last for a minimum time, which varies from six months to two years, according to the regulatory requirements of each country or each defined region. As consequence of the ageing process, the sensory profile of the beverage changes and its quality increases. In fact, the final beverage shows a distinct sensory profile compared to the newly distilled spirit (Léauté et al., 1998; Fiches et al., 2015). These sensory changes can be assessed by using the lexicon for the brandies generated in several studies, by applying the conventional descriptive profiling methods (Caldeira et al., 2002; Peña y Lillo et al., 2005; Caldeira et al., 2006; Fiches et al., 2015) or by using rapid descriptive sensory profiling, such as napping (Louw et al., 2013).

The sensory profile of the aged brandy results firstly from the fermentation and distillation conditions (du Plessis et al., 2002; Lilly et al., 2006), but also from the wooden ageing technology. Technological factors such as the kind of wood, the heat treatment of the barrels (Caldeira et al., 2002, 2006, 2010; Canas et al., 2011) and the ageing time (Léauté et al., 1998; Caldeira et al., 2002; Caldeira et al., 2006; Fiches et al., 2015) also have a strong impact on it.

Concerning the ageing time, it was verified that the intensity of several sensory attributes of the aged brandy (vanilla, woody, dried fruits, toasted, smoke, body, flavor complexity, retronasal aroma and flavor persistence) increase (Léauté et al., 1998; Caldeira et al., 2002, 2006), while the intensities of other attributes, such as alcohol, astringency, fruity, glue, bitterness and burning, decrease. Consequently, the overall quality of the brandy improves (Caldeira et al., 2002, 2006). Fiches et al. (2015) verified that similar perceptions were used to characterize different brandies according to their ageing, supporting the importance of the ageing time.

Other factors, such as the wood origin and the botanical species, and the heat treatment of the barrels, also affect significantly the sensory profile of the brandies (Caldeira et al., 2002, 2006). Regarding the wood species, some works showed interesting sensory characteristics of brandies aged in chestnut barrels in comparison to brandies aged in oak barrels (Caldeira et al., 2002, 2006, 2010, 2013; Canas et al., 2011).

The extraction and the subsequent transformation of compounds from the wood seem to have great importance to the brandy sensory profile. In fact, some studies showed a relationship between the sensory perception and the chemical analysis of several wine spirit volatile compounds (Lablanquie et al., 2002; Ferrari et al., 2004; Caldeira et al., 2008; Janácová et al., 2008; Zhao et al., 2009).

In spite of its broad recognition, the most used ageing technology for brandies and other alcoholic beverages, based on the use of wooden barrels, has some disadvantages resulting from the hard barrel handling, the high costs associated to non-saleable stocks, annual rotation of barrels, insurance of cellar and merchandise, storage costs and evaporation losses.

Therefore, in the last years, alternative technologies have been studied, namely the application of wood fragments inside the beverage kept stainless steel tanks. This technology allows the production of a beverage with a similar quality but with lower costs. Several works about different alcoholic beverages have been done, but for the spirits, the research examining the use of wood fragments, is more limited. There is a work about cider brandy (Rodríguez Madrera et al., 2013), another one evaluated rum (Quesada-Granados et al., 2002) and several studies examined wine brandies (Belchior et al., 2003; Canas et al., 2009a,b, 2013; Caldeira et al., 2010, 2013; Cruz et al., 2012; Anjos et al., 2013; Schwarz et al., 2014; Caldeira et al., 2016; Canas et al., 2016). Nevertheless, the majority of the results obtained are very promising since the use of fragments produced brandies with a similar sensory profile despite having a different chemical composition when compared to the brandies aged in wooden barrels. Schwarz et al. (2014), in a microscale (150 $\mathrm{mL}$ test tubes), studying the accelerated ageing of Jerez brandy using stirring and ultrasound, found different results. These authors concluded that one of the samples presented an orthonasal aroma profile similar to those obtained with traditional process with an average ageing time between 6 and 18 months. These different results are probably due to different kinetics resulting from the low volume and the influence of stirring and ultrasound.

This work aims to evaluate, at industrial scale, the brandy sensory modifications resulting from the use of staves inside stainless steel tanks (3000 L) in comparison with the traditional ageing system (wooden barrels of $650 \mathrm{~L}$ ). In both ageing systems two different kinds of wood (oak and chestnut) were used simultaneously. This innovation intends to obtain aged brandies with the quality and produced without the blending operation, usually made in the final brandy production. 


\section{MATERIAL AND METHODS}

\section{Experimental design and brandy sampling}

The experiment had a factorial design, where the first factor was the ageing system with two levels (traditional ageing in wooden barrels - B and alternative ageing with staves inside the stainless steel tanks $-S$ ) and the second factor was the ageing time with four levels $(6,12,18$ and 24 months). Two replicates of each essay modality were done.

The four experimental units of this experiment, two wooden barrels $(650 \mathrm{~L})$ and two stainless steel tanks (3000 L), were filled with the same wine spirit from Lourinhã region. The wooden barrels were made of Limousin oak (Quercus robur L.) and chestnut (Castanea sativa Mill) with staves arranged alternately. Several staves $(91 \mathrm{~cm}$ length x $5 \mathrm{~cm}$ width $\mathrm{x} 1.8 \mathrm{~cm}$ thickness) from the two types of wood were also arranged alternately inside the stainless steels tanks. The number of staves was calculated in order to reproduce the surface area to volume ratio of a 650 L barrel.

The cooperage (J.M. Gonçalves at Palaçoulo, Portugal) made the wooden barrels and the staves, and both were submitted to a medium plus toasting level (90 min at an average temperature of $240{ }^{\circ} \mathrm{C}$ ). The barrels were heated over a fire of wood offcuts and the staves were heated in an industrial oven.

The wine spirit was produced by Adega Cooperativa da Lourinhã - ACL (Lourinhã, Portugal) and its chemical composition is presented in Table I. The alcoholic strength was determined by distillation and electronic densimetry, the dry extract was evaluated by gravimetry and the $\mathrm{pH}$ was determined by using a potentiometer Crison, according to the methods from OIV (2014). The total acidity was determined by titrimetry (Belchior and Carvalho, 1984) and the major volatiles compounds (acetaldehyde, ethyl acetate, methanol and fusel alcohols) were analysed by gas chromatography-flame ionization detector (GC-FID) according to the methodology previously validated (Luís et al., 2011).

The four experimental units (two wooden barrels and two stainless steel tanks) were placed in similar conditions in the ACL cellar. About $2 \mathrm{~L}$ of brandy from each experimental unit were sampled over the time, respectively at $6,12,18$ and 24 months of ageing. All the sixteen brandy samples were evaluated through sensory analysis.
TABLE I

Chemical composition of Lourinhã wine spirit used in the experiment

Composição química da aguardente vínica Lourinhã utilizada no estudo

\begin{tabular}{ll}
\hline Alcoholic strength by volume (\% vol.) & 77.3 \\
Dry matter (g/L) & 0.00 \\
Total acidity (g of acetic acid/L) & 0.10 \\
pH & 5.45 \\
Acetaldehyde (g/L) & 0.01 \\
Ethyl acetate (g/L) & 0.69 \\
Methanol (g/L) & 0.42 \\
1-Propanol (g/L) & 0.27 \\
Isobutanol (g/L) & 0.71 \\
2-Butanol (g/L) & 0.01 \\
2+3 Methyl butanol (g/L) & 1.37 \\
\hline
\end{tabular}

\section{Sensory analysis}

\section{Sensory attributes}

The sensory score sheet included attributes generated formerly (Caldeira et al., 1999). This score sheet comprised thirty three sensory attributes, namely five visual, sixteen olfactory and twelve gustatory attributes. The panelists were asked to score the intensity of each attribute using a structured scale ranging from 0 (no perception) to 5 (highest perception).

The overall quality of the brandies, which characterizes the assessor perception about the brandy, in view of the absence or presence of defects and the ageing characteristics, was also rated between 0 (without quality) and 20 (maximum quality).

\section{Sensory panel}

From an established 19 volunteer member panel, with several years of experience in descriptive sensory analysis of brandies, eight panelists ( 5 females and 3 males, 36-73 years of age) were selected based on their availability. The number of judges is in accordance to the minimum suggested by Heymann et al. (2012) to descriptive sensory analysis. The panelists were all trained according to the international standards (ISO 8586) comprising detection and recognition of tastes and odors, as well as the use of scales. Before and during this study, monthly training sessions were carried out to assess numerous flavor standards (1-hexanol, acetic acid, apple extract, banana extract, caramel extract, cis-3- 
hexenol, cloves extract, dried figs extract, ethanol, ethyl acetate, ethyl butyrate, eugenol, geraniol, grain coffee extract, guaiacol, head distillation fractions, honey extract, isoamyl acetate, jam extract, linalool, methylcetones, nuts extract, oak and chestnut extracts, raisin extract, syringol, tail distillation fractions, vanillin, $\beta$-methyl- $\gamma$-octalactone) and several samples of freshly distilled and aged brandies.

Panelist's performance was monitored by evaluating its reliability and panel homogeneity, calculated through the analysis of the sensory results of brandy duplicate samples (Caldeira et al., 2002).

\section{Tasting conditions}

It was used a standardized tasting room equipped with individual white booths and standard wine-tasting glasses (ISO 3591) filled with approximately $30 \mathrm{~mL}$ of diluted brandies. Brandy samples were previously diluted (15 days before) with water, in order to decrease the alcoholic strength by volume until $40 \%$ $\mathrm{v} / \mathrm{v}$ and they were preserved in closed bottles, on a dark room at $20^{\circ} \mathrm{C}$, until the sensory session.

In the sensory sessions, which were done in the morning (10 a.m.), the samples were served at room temperature $\left(21^{\circ} \mathrm{C} \pm 1{ }^{\circ} \mathrm{C}\right)$.

Water was provided to the panellists for rinsing their mouth between samples.

\section{Descriptive sensory analysis}

Brandy sensory assessment took place over two years, in four sensory sessions at $6,12,18$ and 24 months of brandy ageing. In each sampling time, the panelists evaluated the four brandies coming from the four experimental units. The samples were presented in balanced order to eliminate first-order carryover effects (MacFie et al., 1989). The panelists were first asked to evaluate the color attributes, followed by the orthonasal odor, the retronasal odor and the mouthfeeel attributes of the sample. Panelists were required to rest for a minimum time of $60 \mathrm{~s}$ between samples and to clean their palates with water. In order to control the reliability of the panelists, two replicates were introduced in all sessions.

\section{Data analysis}

The analysis of variance (ANOVA) of descriptive sensory results was made through Statgraphics statistical system (vs 7.0). The ANOVA factors were ageing system, ageing time and panelists, as fixed factors, and their interactions (Lea et al., 1997). It was chosen a statistically significant level of $1 \%$ $(p<0.01)$. When a significant effect was verified, the calculations of the Fischer's least significant difference (LSD) were applied to the multiple comparisons.
Principal components analysis (PCA) was also applied to the average of the panelist's records to study the relationship between products and attributes. The calculations were performed on NTSYS-pc package, version 2.1q (Rohlf, 2000).

\section{RESULTS AND DISCUSSION}

\section{Color attributes}

The brandies color description was based on the scores of five attributes namely yellow-green, yellowstraw, golden, topaz and greenish.

The ANOVA results (Table II) show that yellowgreen, yellow-straw, golden and topaz are significantly affected by ageing time, while the ageing system only affected the golden and topaz intensities. The interaction of the two factors also influenced significantly the golden and topaz attributes.

The yellow-green attribute was only assigned in the first sampling of the brandies, after six months of ageing (Figure1). After this sampling, the intensity of this attribute decrease to zero. The yellow-straw also decreased over time in the two ageing systems. The golden shows a similar behavior, its intensity also decreased over time, but the average values are significantly higher in the brandies aged in barrels than in stainless steel tanks with staves. Moreover, the golden intensity decrease was more pronounced in the brandies aged in stainless steel tanks with staves. Concerning the topaz attribute, its intensity was higher in brandies aged in stainless steel tanks with staves than in brandies aged in barrels, and it was verified an increase of its intensity over time, which was less pronounced in the brandies aged in barrels (Figure 1). These results are in agreement with those obtained at pilot-scale (Caldeira et al., 2010, 2013). Taking into account the increase of topaz color over time, which takes place in traditional ageing system (Canas et al., 2000), it seems that the brandies aged in an alternative system (S) presented a more evolved color; that is, a color related to longer aging times in wood.

\section{Olfactory attributes}

The intensity of sixteen attributes, namely alcohol, fruity, vanilla, woody, rancid, spicy, caramel, toasted, dried fruits, smoke, coffee, sweet, green, tails, glue and caoutchouc, was scored by each panelist in order to assess the aroma of brandy samples. The ageing system only influenced four attributes, whereas the ageing time was a more discriminative factor, influencing eight attributes (Table II). 


\section{TABLE II}

$p$ values obtained in ANOVA of color attributes, olfactory attributes gustatory attributes and of overall quality results (the values higher than 0.01 are assigned as ns).

Valores de p obtidos na ANOVA para os resultados dos atributos de cor, olfato e sabor e para a qualidade global (valores mais elevados do que 0.01 são assinalados como ns).

\begin{tabular}{|c|c|c|c|c|}
\hline \multicolumn{2}{|c|}{ Attributes } & \multicolumn{3}{|c|}{ Factors } \\
\hline & & Ageing system (S) & Ageing time $(\mathrm{T})$ & S-T interaction \\
\hline \multirow{4}{*}{ Color attributes } & Yellow-green & 0.321 (ns) & 0.000 & 0.398 (ns) \\
\hline & Yellow-straw & 0.026 (ns) & 0.001 & $0.283(\mathrm{~ns})$ \\
\hline & Golden & 0.003 & 0.000 & 0.007 \\
\hline & Topaz & 0.000 & 0.000 & 0.007 \\
\hline \multirow{16}{*}{ Olfactory attributes } & Alcohol & 0.953 (ns) & 0.07 (ns) & 0.746 (ns) \\
\hline & Fruity & 0.775 (ns) & 0.003 & 0.996 (ns) \\
\hline & Vanilla & 0.485 (ns) & 0.937 (ns) & 0.185 (ns) \\
\hline & Woody & 0.000 & 0.217 (ns) & 0.407 (ns) \\
\hline & Rancid & 0.860 (ns) & 0.000 & 0.331 (ns) \\
\hline & Spicy & 0.731 (ns) & 0.096 (ns) & 0.186 (ns) \\
\hline & Caramel & 0.002 & 0.042 (ns) & $0.415(\mathrm{~ns})$ \\
\hline & Toasted & 0.972 (ns) & 0.001 & 0.204 (ns) \\
\hline & Dried fruits & 0.283 (ns) & 0.163 (ns) & 0.243 (ns) \\
\hline & Smoke & 0.977 (ns) & 0.000 & 0.931 (ns) \\
\hline & Coffee & 0.001 & 0.000 & 0.903 (ns) \\
\hline & Sweet & 0.061 (ns) & 0.043 (ns) & 0.553 (ns) \\
\hline & Green & 0.002 & $0.065(\mathrm{~ns})$ & 0.321 (ns) \\
\hline & Tails & 1.000 (ns) & 0.001 & 0.531 (ns) \\
\hline & Glue & 0.441 (ns) & 0.000 & 0.864 (ns) \\
\hline & Caoutchouc & 0.205 (ns) & 0.000 & 0.190 (ns) \\
\hline \multirow{12}{*}{ Gustatory attributes } & Sweetness & 0.717 (ns) & 0.058 (ns) & 0.211 (ns) \\
\hline & Smooth & 0.409 (ns) & $0.074(\mathrm{~ns})$ & 0.178 (ns) \\
\hline & Burning & 0.348 (ns) & 0.000 & $0.413(\mathrm{~ns})$ \\
\hline & Astringency & 0.016 (ns) & 0.016 (ns) & 0.362 (ns) \\
\hline & Roughness & 0.492 (ns) & 0.000 & 0.773 (ns) \\
\hline & Bitterness & 0.165 (ns) & 0.454 (ns) & 0.873 (ns) \\
\hline & Body & 0.043 (ns) & 0.000 & 0.466 (ns) \\
\hline & Unctuous & 0.005 & 0.043 (ns) & 0.386 (ns) \\
\hline & Flavor evolution & 0.119 (ns) & 0.000 & 0.087 (ns) \\
\hline & Flavor complexity & 0.107 (ns) & 0.000 & 0.777 (ns) \\
\hline & Retronasal aroma & 0.125 (ns) & 0.001 & 0.089 (ns) \\
\hline & Flavor persistence & 0.475 (ns) & 0.000 & 0.847 (ns) \\
\hline Overall quality & & 0.005 & 0.005 & 0.341 (ns) \\
\hline
\end{tabular}




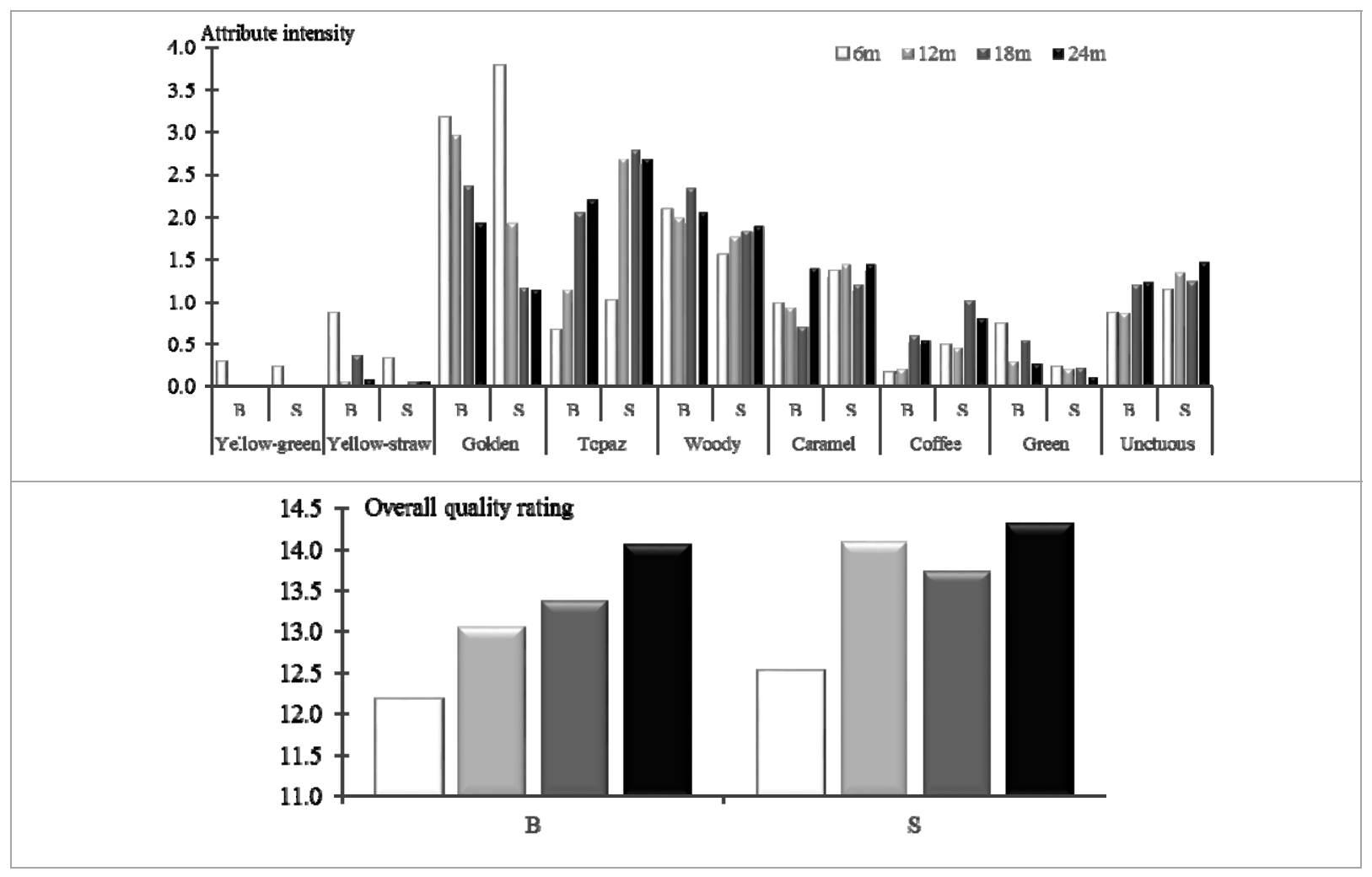

Figure 1. Average values, from ANOVA results, of color attributes (yellow-green, yellow-straw, golden and topaz) olfactory attributes (woody, caramel, coffee and green), gustatory attributes (unctuous) and overall quality for the brandies over time (6 months=6m; $12 \mathrm{months}=12 \mathrm{~m}$; 18 months $=18 \mathrm{~m} ; 24$ months $=24 \mathrm{~m}$ ) in the two ageing systems (wooden barrel-B and stainless steel tank with staves inside-S).

Valores médios dos resultados da ANOVA para os atributos de cor, (citrino, palha, dourado e topazio) de olfato (madeira, caramelo,

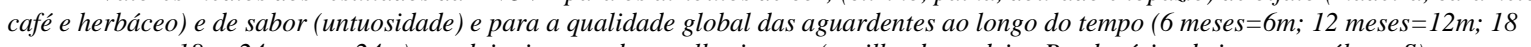
meses $=18 \mathrm{~m} ; 24$ meses $=24 \mathrm{~m}$ ) nos dois sistemas de envelhecimento (vasilha de madeira-B e depósito de inox com tábuas-S).

The ageing system influenced significantly the woody, caramel, coffee and green attributes (Table II). The brandies aged in stainless steel tanks with staves presented higher intensity of caramel and coffee attributes and lower intensity of woody and green attributes than the brandies aged in barrels (Figure 1).

Taking into account that caramel, coffee, woody attributes have been assigned to the presence of different volatile compounds in aged brandies (Caldeira et al., 2008; Janácová et al., 2008), it would be expectable that sensory differences between the brandies proceeding from the two ageing systems were the result of differences in volatile composition. In fact, our previous results (Caldeira et al., 2016) revealed significant differences in the amounts of the volatile compounds of the brandies proceeding from the two ageing systems. However, there is no accordance in the differences pointed out to the volatiles compounds and the differences in the corresponding flavor notes. Further research is needed in order to understand this subject.
The green attribute, related to the presence of alcohols in the aged brandies (Caldeira et al., 2008), is usually negatively correlated with the overall quality (Caldeira et al., 2006, 2013) and with the age of brandies (Léauté et al., 1998; Caldeira et al., 2013). Therefore, the lower intensity of this attribute in the brandies aged in stainless steel tanks with staves can mean that this alternative system allowed a more accelerated ageing process.

As expected, the ageing time influences significantly the aroma attributes - fruity, rancid, toasted, smoke, coffee, tails, glue and caoutchouc (Table II) - which is in accordance with previous results obtained with Cognac and Lourinhã brandies (Léauté et al., 1998; Caldeira et al., 2006, 2013). The intensity of rancid, toasted, smoke and coffee increased over time, while the other attributes decreased (Figure 2). It worth to point out that there was no significant interaction between the ageing system and the ageing time (Table II), meaning that the behavior over time, in a sensory point of view, was similar in the two ageing systems. 


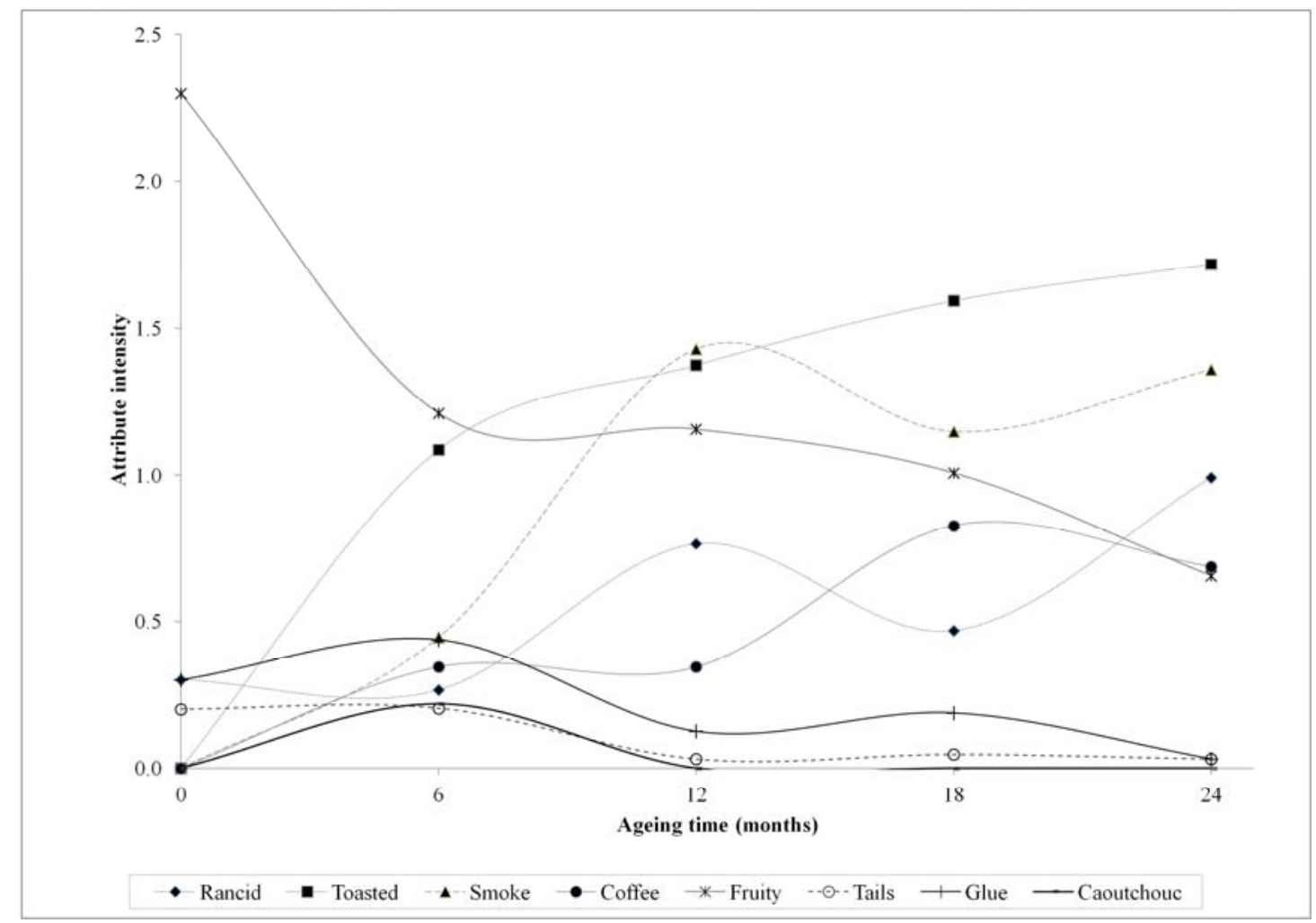

Figure 2. Average values, from ANOVA results, of olfactory attributes rancid, toasted, smoke, coffee, fruity, glue, tails and caoutchouc over time.

Valores médios dos resultados da ANOVA relativos a atributos do olfato ranço bom, torrado, fumo, café, frutado, cola, caudas e borracha ao longo do tempo.

\section{Flavor attributes}

The mouthfeel perception of the brandies is based in the evaluation of the twelve attributes: sweetness, smooth, burning, astringency, roughness, bitterness, body, unctuous, flavor evolution, flavor complexity, retronasal aroma and flavor persistence.

The ANOVA results (Table II) showed that the ageing system only affected the unctuous attribute, which is higher in brandies aged in stainless steel with staves (Figure 1)

As observed in olfactory attributes, the ageing time is a very significant factor, influencing the intensity of burning, roughness, body, flavor evolution, flavor complexity, retronasal aroma and flavor persistence (Table II). As expected, according to our previous results (Caldeira et al., 2006), many sensory modifications occurred during the ageing process, namely the decrease of burning and roughness and the increase of body, retronasal aroma and flavor evolution, complexity and persistence (Figure 3).
The panel also rated the overall quality of the brandies, which was significantly affected by the ageing time and by the ageing system (Table II). The effect of ageing time was expected because it is well known that several sensory modifications occur over the ageing time (Léauté et al., 1998). These modifications have been assessed by the increase and decrease of different sensory attributes, enhancing brandy’s overall quality (Caldeira et al. 2006, 2013).

Regarding the overall quality of the brandies, statistical differences were found, although its similarity in the two systems: the brandies aged in stainless steel tanks with staves showed a significantly higher overall quality than the brandies aged in wooden barrels. A similar trend was detected at pilot scale, but without significant results (Caldeira et al., 2013). This higher overall quality may result from the highest scores of topaz, caramel, coffee and unctuous attributes, which are positively correlated with overall quality of brandies (Caldeira et al., 2006). 


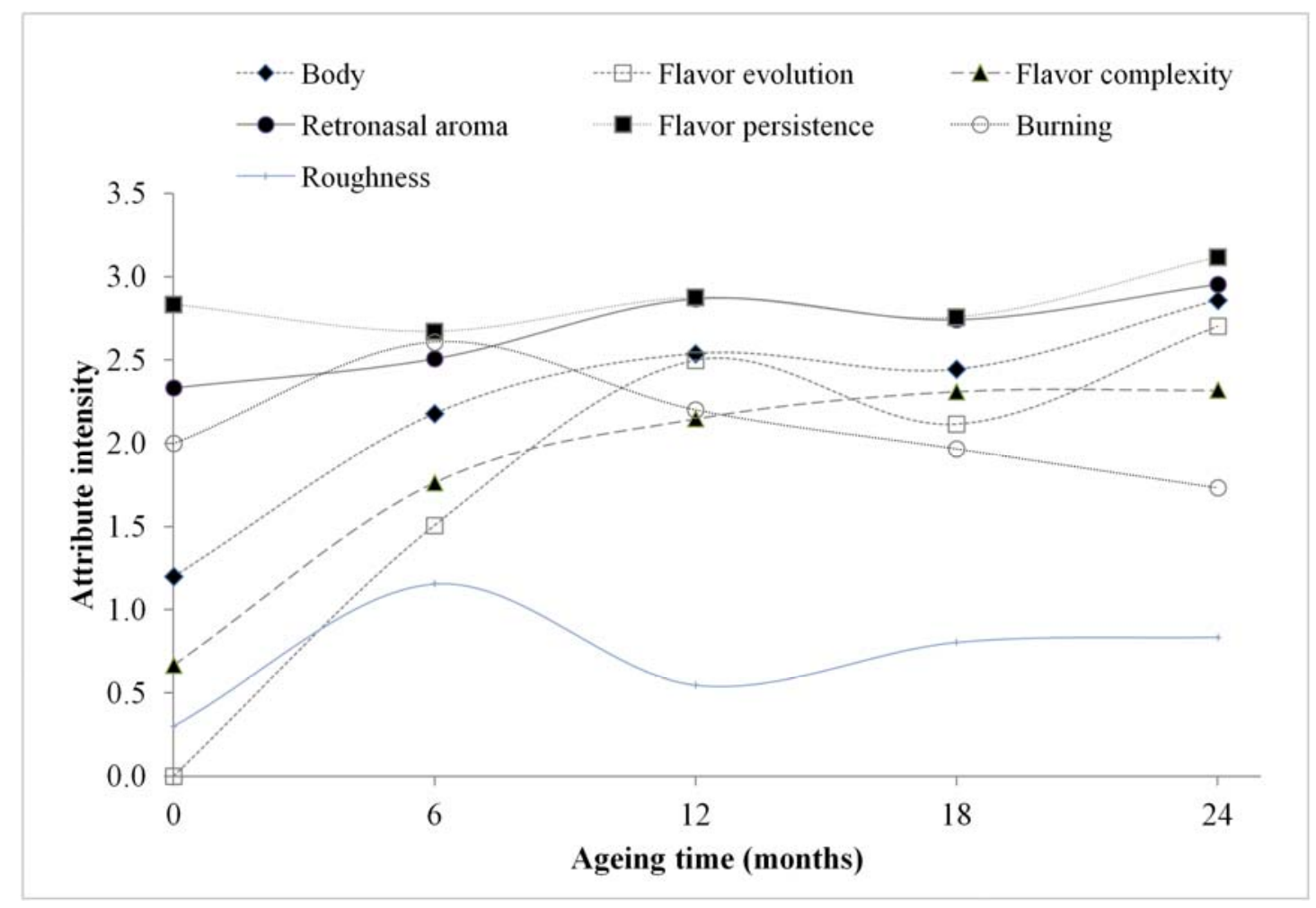

Figure 3. Average values over the time, from ANOVA results, of gustatory attributes burning, roughness, body, flavor evolution, retronasal aroma, flavor complexity and flavor persistence.

Valores médios ao longo do tempo, obtidos a partir dos resultados da ANOVA para os atributos de sabor: queimante, aspereza, corpo, evolução, aroma retronasal, complexidade e persistência.

It is also important to point out that, after only two years of ageing, the overall quality attained similar values to those presented by brandies with a long ageing time (Caldeira et al., 2006). This may result from the innovative procedure introduced in this experiment by using Limousin oak and chestnut simultaneously.

\section{Multivariate analysis results}

Taking into account the interesting results presented, that lead to propose an alternative method for the wine brandy production, it was important to check whether sensory variables could help to discriminate the pre-established groups (ageing systems).

Based on this idea, a principal components analysis was applied to the averaged sensory data results from the panelists, in order to understand if some sensory attributes would be helpful to screen the variability among the samples proceeding from the two ageing systems. According to the previous ANOVA results, the sensory variables that were significantly affected by the ageing system and/or the ageing time were chosen, namely five color attributes, eleven olfactory attributes and eight gustatory attributes. The scatterplot of the 24 brandy samples, in the plan defined by the first two principal components (Figure 4 ), which accounted for $66 \%$ of the total variance, reveals the splitting of brandy samples across the first component based on the ageing time. In fact, the brandies with 6 months of ageing were located in the positive branch of this component, where the variables with the highest loads in this side of the component were green, golden and burning. In the opposite side, corresponding to the negative branch of this component, were located the brandies with 24 months of ageing, associated with the variables topaz, toasted, smoke, body, flavor evolution and flavor complexity. Nevertheless, the distribution of the brandy samples in the graph does not appear to be influenced by the aging system.

These results are in agreement with those of ANOVA and with other obtained in previous studies (Caldeira et al., 2006; Caldeira et al., 2013; Fiches et al., 2015). They pointed out the ageing time as the most 
discriminative factor among other factors. However, these results are quite different from those obtained with wines, showing the possibility of the sensory discrimination of samples based on the ageing system (Afonso, 2002; Cano-López et al., 2008; OrtegaHeras et al., 2010).

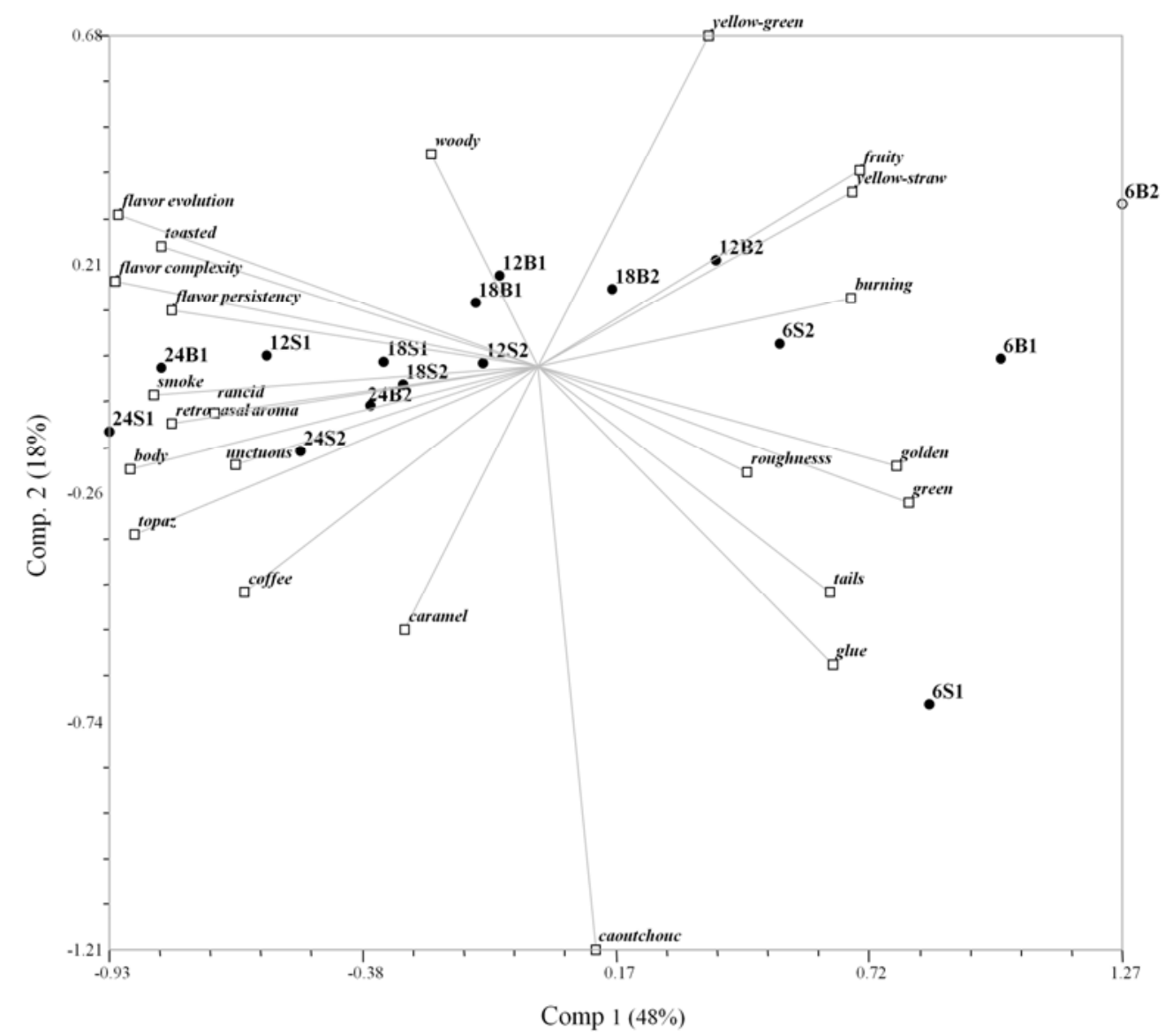

Figure 4. Principal component analysis of sensory data averaged across the eight panelists. Scatterplot of brandy samples onto the plane defined by the two first components. Symbols: black circles (brandy samples) and empty squares (sensory attributes) (the brandy samples are identified by a first number that indicate the ageing time: $6,12,18$ or 24 , a second letter that identify the ageing system: B-barrels, S-stainless steel tank with staves and a third number that identify the replicate experiment 1 or 2 ).

Analise em componentes principais dos valores médios dos oito provadores obtidos na análise sensorial. Gráfico das amostras de aguardentes no plano definido pelas duas primeiras componentes. Símbolos: círculos negros (amostras de aguardente) e quadrados vazios (atributos sensoriais) (as amostras de aguardente estão identificadas primeiramente com um número que indica o tempo de envelhecimento: 6, 12, 18 ou 24, depois com uma letra que identifica o sistema de envelhecimento: B-vasilhas, S-depósitos de aço inox com tábuas e em terceiro com um número que indica a réplica de ensaio 1 ou 2).

\section{CONCLUSIONS}

The changes in the sensory profile of the same Lourinhã brandy aged in wooden barrels and in stainless steel tanks with staves of the same wood inside, using alternatively two species, during an ageing period of 24 months were evaluated, at industrial scale.

The brandies aged in stainless steel tanks with staves presented higher intensity of attributes such as topaz, coffee, caramel and unctuous, and lower intensity of golden, woody and green attributes, and higher overall quality than the same wine distillate aged in wooden barrels. Regardless these differences, it is not possible to clearly distinguish the brandy samples proceeding from the different ageing systems by the multidimensional analysis of data.

On the other hand, the use of Limousin oak and chestnut simultaneously seems to be an interesting option, considering the quality achieved by the aged 
brandies combined with a lower cost of the barrels and the exemption of the blending operation. Nevertheless, further experiments are needed to confirm these advantages.

\section{ACKNOWLEDGMENTS}

The authors are grateful to the sensory panel. The authors also thank the technical support of Deolinda Mota and Sandra Amado.

\section{REFERENCES}

Afonso V.L.G., 2002. Sensory descriptive analysis between white wines fermented with oak chips and in barrels. J. Food Sci., 67, 2415-2419.

Anjos O., Carmona C., Caldeira I., Canas S., 2013. Variation of Extractable Compounds and Lignin Contents in Wood Fragments Used in the Aging of Wine Brandies. Bioresources, 8, 4484-4496.

Belchior A.P., Almeida T.G.T., Mateus A.M., Canas S., 2003. Ensaio laboratorial sobre a cinética de extracção de compostos de baixa massa molecular da madeira pela aguardente. Ciência Téc. Vitiv., 18, 29-41.

Belchior A.P., Carvalho E.C., 1984. Métodos de Análise de Aguardentes. I. Análise Clássica. Instituto Nacional de Investigação Agrária e de Extensão Rural. Estação Vitivinícola Nacional, Dois Portos.

Caldeira I., Anjos O., Portal V., Belchior A.P., Canas S., 2010. Sensory and chemical modifications of wine-brandy aged with chestnut and oak wood fragments in comparison to wooden barrels. Anal. Chim. Acta, 660, 43-52.

Caldeira I., Belchior A.P., Canas S., 2013. Effect of alternative ageing systems on the wine brandy sensory profile. Ciência Téc. Vitiv., 28, 9-18.

Caldeira I., Belchior A.P., Clímaco M.C., Bruno de Sousa R., 2002. Aroma profile of Portuguese brandies aged in chestnut and oak woods. Anal. Chim. Acta, 458, 55-62.

Caldeira I., Bruno de Sousa R., Belchior A.P., Clímaco M.C., 2008. A sensory and chemical approach to the aroma of wooden aged Lourinhã wine brandy. Ciência Téc. Vitiv., 23, 97-110.

Caldeira I., Canas S., Costa S., Carvalho E., Belchior A.P., 1999. Formação de uma câmara de prova organoléptica de aguardentes velhas e selecção de descritores sensoriais. Ciência Téc. Vitiv., 14, 21-30.

Caldeira I., Mateus A.M., Belchior A.P., 2006. Flavour and odour profile modifications during the first five years of Lourinhã brandy maturation on different wooden barrels. Anal. Chim. Acta, 563, 264-273.

Caldeira I., Santos R.., Ricardo-da-Silva J.M., Anjos O., Mira H., Belchior A.P., Canas S. 2016. Kinetics of odorant compounds in wine brandies aged in different systems. Food Chem., 211, 937946.

Canas S., Belchior A.P., Caldeira I., Spranger M.I., Bruno de Sousa R., 2000. La couleur et son évolution dans les eaux-de-vie Lourinhã pendant les trois premières années du vieillissement. Ciência Téc. Vitiv., 15, 1-14.

Canas S., Caldeira I., Anjos O., Lino J., Soares A., Belchior A.P., 2016. Physicochemical and sensory evaluation of wine brandies
This work had the financial support of Tanoaria J. M. Gonçalves, Adega Cooperativa de Lourinhã, Instituto Politécnico de Castelo Branco and Instituto Nacional de Investigação Agrária e Veterinária, IP. This work is also funded by National Funds through FCT Foundation for Science and Technology under the Project UID/AGR/00115/2013.

Centro de Estudos Florestais is a research unit funded by FCT (PEst-OE/AGR/UI0239-2013).

aged using oak and chestnut wood simultaneously in wooden barrels and in stainless steel tanks with staves. Int. J. Food Sci. Technol., 51, 2537-2545.

Canas S., Caldeira I., Belchior A.P., 2009a. Comparação de sistemas alternativos para o envelhecimento de aguardente vínica. Efeito da oxigenação e da forma da madeira. Ciência Téc. Vitiv. 24, 33-40.

Canas S., Caldeira I., Belchior A.P., 2009b. Comparison of alternative systems for the ageing of wine brandy. Wood shape and wood botanical species effect. Ciência Téc. Vitiv., 24, 90-99.

Canas S., Caldeira I., Belchior A.P., 2013. Extraction/oxidation kinetics of low molecular weight compounds in wine brandy produced in alternative ageing systems. Food Chem., 138, 24602467.

Canas S., Caldeira I., Belchior A.P., Spranger M.I., Clímaco M.C., Bruno de Sousa R. (2011) Chestnut wood: a sustainable alternative for the aging of wine brandies. In: Food Quality: Control, Analysis and Consumer Concerns. 181-228. Medina D.A., Laine A.M. (eds), Nova Science Publishers Inc, New York.

Cano-López M., Bautista-Ortín A.B., Pardo-Mínguez F., LópezRoca J.M., Gómez-Plaza E., 2008. Sensory descriptive analysis of a red wine aged with oak chips in stainless steel tanks or used barrels: effect of the contact time and size of the oak chips. J. Food Quality, 31,645-660.

Cruz S., Canas S., Belchior A.P., 2012. Effect of ageing system and time on the quality of wine brandy aged at industrial-scale. Ciência Téc. Vitiv., 27, 83-93.

du Plessis H.W., Steger C.L.C., du Toit M., Lambrechts M.G., 2002. The occurrence of malolactic fermentation in brandy base wine and its influence on brandy quality. J. Appl. Microbiol., 92, 1005-1013.

Ferrari G., Lablanquie O., Cantagrel R., Ledauphin J., Payot T., Fournier N., Guichard E., 2004. Determination of key odorant compound in freshly distilled Cognac using GC-O, GC-MS and sensory evaluation. J. Agric. Food Chem., 52, 5670-5676.

Fiches G., Saint Eve A., Jourdren S., Déléris I., Brunerie P., Souchon I., 2015. Temporality of perception during the consumption of French grape brandies with different aging times in relation with aroma compound release. Flavour Fragr. J., 31, 3140 .

Heymann H., Machado B., Torri L., Robinson A.L., 2012. How many judges should one use for sensory descriptive analysis? $J$. Sens. Stud., 27, 111-122.

ISO-International Organization for Standardization. ISO standard 3591, 1977. Sensory analysis - Apparatus -Wine-tasting glass. This standard was last reviewed in 2010.

ISO-International Organization for Standardization. ISO standard 
8586, 2012. Sensory analysis - General guidelines for the selection, training and monitoring of selected assessors and expert sensory assessors.

Janácová A., Sádecká J., Kohajdová Z., Spanik I., 2008. The identification of aroma-active compounds in Slovak brandies using GC-sniffing, GC-MS and sensory evaluation. Chomatographia, 67, 113-121.

Lablanquie O., Cantagrel R., Ferrari G., 2002. Characterisation of young Cognac spirit aromatic quality. Anal. Chim. Acta, 458, 191196.

Lea P., Næs T., Rødbotten M., 1997. Analysis of variance for sensory data. 102 p. John Wiley \& Sons, Chichester.

Léauté R., Mosedale J.R., Mourgues J., Puech J.L., 1998. Barrique et vieillissement des eaux-de-vie In: Oenologie fondements scientifiques et technologiques. Flanzy C. (ed.), 1085-1142. Tec \& Doc-Lavoisier, Paris.

Lilly M., Bauer F.F., Styger G., Lambrechts M.G., Pretorius I.S., 2006. The effect of increased branched-chain amino acid transaminase activity inyeaston the production of higher alcohols and on the flavour profiles of wine and distillates. FEMS Yeast Res., 6, 726-743.

Louw L., Malherbe S., Naes T., Lambrechts M., van Rensburg P., Nieuwoudt H., 2013. Validation of two Napping techniques as rapid sensory screening tools for high alcohol products. Food Qual. Prefer., 30, 192-201.

Luís A., Mota D., Anjos O., Caldeira I., 2011. Single-laboratory validation of determination of acetaldehyde, ethyl acetate, methanol and fusel alcohols in wine spirits, brandies and grape marc spirits using GC-FID. Ciência Téc. Vitiv., 26, 69-76.

Macfie H.J.M., Bratchell N., Greenhoff H., Vallis L.V., 1989. Designs to balance the effects of order of presentation and first order carryover effects in hall tests. J. Sens. Stud., 4, 129-148.

OIV, 2014. Compendium of international methods of analysis of spirituous beverages of vitivinicultural origin. OIV, Paris.

Ortega-Heras M., Pérez-Magariño S., Cano-Mozo E., GonzálezSan José M.L., 2010. Differences in the phenolic composition and sensory profile between red wines aged in oak barrels and wines aged with oak chips. LWT-Food Sci. Technol., 43, 1533-1541.

Peña y Lillo M., Latrille E., Casaubon G., Agosin E., Bordeu E., Martin N., 2005. Comparison between odour and aroma profiles of Chilean Pisco spirit. Food Qual. Pref., 16, 59-70.

Quesada-Granados J., Merelo-Guervós J.J., Oliveras-López M.J., González-Peñalver J., Olalla-Herrera M., Blanca Herrera R., López Martinez M.C., 2002. Application of Artificial Aging Techniques to Samples of Rum and Comparison with Traditionally Aged Rums by Analysis with Artificial Neural Nets. J. Agric. Food Chem., 50, 1470-1477.

Rodríguez Madrera R.R., García Hevia A., Suárez Valles B., 2013. Comparative study of two aging systems for cider brandy making. Changes in chemical composition. LWT-Food Sci. Technol., 54 513-520.

Rohlf F.J., 2000. NTSYS-pc: Numerical taxonomy and multivariate analysis system. 130 p. Exeter Software, New York.

Schwarz M., Carmen Rodríguez M., Sánchez M., Guillén D.A., Barroso C.G., 2014. Development of an accelerated aging method for Brandy. LWT-Food Sci. Technol., 59, 108-114.

Zhao Y., Jiming L., Yan X., Fan W., Jiang W., 2009. Characterization of aroma compounds of four brandies by aroma extract dilution analysis. Am. J. Enol. Vitic., 60, 269-276. 